\title{
International Trade Policy During COVID-19
}

Fernando Leibovici, Economist

Ana Maria Santacreu, Senior Economist nternational trade has played an important role during the ongoing COVID-19 pandemic. As the pandemic has created massive shortages of essential medical equipment, many countries have been resorting to trade policy to maintain adequate supplies. While some countries have adopted export restrictions on essential medical equipment, others have reduced tariffs on these goods. ${ }^{1}$

Our working paper, "International Trade of Essential Goods During a Pandemic," 2 documents that trade policy during the COVID-19 pandemic has been systematically related to countries' trade imbalances in essential medical equipment. We combine data on trade policy for essential medical equipment since March 2020 with data on imports and exports of these goods for 109 countries during 2018. ${ }^{3}$ About 86 percent of countries with a medical equipment surplus in 2018 have restricted exports, but only 46 percent of the countries running deficits in these goods have. Similarly, only about 18 percent of countries with a surplus in these goods have reduced import barriers on them, whereas almost 30 percent of net importers have. ${ }^{4}$

Recent trade policy implemented to avoid shortages of essential medical equipment amid COVID-19 has been related to the country's trade imbalances in these goods.

The need to resort to trade restrictions on essential medical equipment raises the question of how to avoid shortages of these goods in the short and long term.

In the very short term, affected countries may design policies to boost domestic production of essential medical equipment. During the current pandemic, for instance, the U.S. government directed private companies, such as auto manufacturers, to produce ventilators. In the medium and long term, it is important to agree on trade policies that ensure the benefits of trade while minimizing the costs of a global pandemic. ${ }^{5}$ One possibility would be to create a global reserve of essential medical equipment to which all countries contribute. During a pandemic, countries could
Trade Imbalances and Trade Policy

\begin{tabular}{lccc} 
Sector & $\begin{array}{c}\text { Trade } \\
\text { imbalance (\%) }\end{array}$ & $\begin{array}{c}\text { Average } \\
\text { tariff (\%) }\end{array}$ & $\begin{array}{c}\text { Non-tariff } \\
\text { barrier (\%) }\end{array}$ \\
\hline Defense & -13.9 & 7.2 & 90.6 \\
\hline Food & -5.9 & 7.9 & 92.6 \\
Medical & -33.2 & 1.7 & 74.5 \\
\hline Non-essential & -14.9 & 5.4 & 50.2 \\
\hline
\end{tabular}

NOTE: Sectoral trade imbalances are computed as the ratio of net exports to total trade. Net exports are computed as the difference between exports and imports.

get equipment from this reserve. As countries start recovering, they could be required to contribute again to the world reserve. ${ }^{6}$ Whichever the case-to boost domestic production in the short term or create a global reserve-countries should have some capacity to boost domestic production of essential goods, both for self-insurance purposes and to assist other countries as part of a global risk-sharing agreement.

Other types of essential goods are also subject to shocks and may potentially affect trade policy. Indeed, the patterns of international trade and trade policy vary systematically in sectors traditionally considered essential, such as food and defense, relative to those for non-essential goods. We combine international trade data at the product level with data on trade restrictions for 109 countries in $2018 .{ }^{7} \mathrm{We}$ then consider trade in three essential sectors (defense, food, and medical) and an aggregate non-essential product sector. The table below reports the trade imbalances, tariffs, and non-tariff barriers (e.g., export restrictions or import quotas) for each sector, averaged across countries.

The first column of the table shows that trade is more balanced in traditional essential goods (food and defense) than in non-essential goods. That is, while all imbalances are negative on average, non-essential goods feature a larger trade deficit $(-14.9$ percent) on average than does food ( -6 percent) or defense ( -13.9 percent). Trade of medical goods is unusual in that it features a larger trade imbalance than both non-essential and traditional essential goods. 
The second column of the table shows that governments impose higher average tariffs on traditional essential goods (defense and food) than on non-essential goods (7.2 percent and 7.9 percent versus 5.4 percent, respectively). In contrast, tariffs on imports of medical goods are only 1.7 percent, which is low both in absolute and relative terms.

Finally, the third column of the table shows that nontariff barriers are significantly more prevalent on essential than on non-essential goods. ${ }^{8}$ More than 90 percent of traded defense goods and food are each subject to some type of non-tariff barriers, while only 50 percent of nonessential goods are.

To summarize, a country's net trade in essential medical goods, that is, whether it is a net importer or exporter, determines its trade policy to avoid shortages of such goods during a pandemic. More generally, governments implement higher trade barriers for essential goods than for nonessential goods. The challenge is to design trade agreements that allow countries to reap the benefits from international trade while ensuring access to essential goods during a negative shock.

\section{Notes}

1 For a list of countries, see https://ww.worldbank.org/en/topic/trade/brief/ coronavirus-covid-19-trade-policy-database-food-and-medical-products.

2 Leibovici, Fernando and Santacreu, Ana Maria. "International Trade of Essential Goods During a Pandemic." Working Paper 2020-010B, Federal Reserve Bank of St. Louis, 2020; https://research.stlouisfed.org/wp/more/2020-010.

${ }^{3}$ Global Trade Alert provides trade policy data, while UN COMTRADE provides imports and exports by product. UNCOMTRADE product data is at the HS (harmonized system) 6-digit level of disaggregation.

${ }^{4}$ Trade surplus is the difference between exports and imports.

5 Several authors contributing to the following recent eBook on COVID-19 and trade policy have argued in favor of more international trade coordination: Baldwin, Richard and Evenett, Simon, eds. COVID-19 and Trade Policy: Why Turning Inward Won't Work. VOX, 2020; https://voxeu.org/content/covid19-and-trade-policy-why-turning-inward-won-t-work.

${ }^{6}$ A similar system has been implemented for food products to reduce volatility in food markets that are facing supply shortages (see https://worldfoodbank.org/).

7 International trade data are from UNCOMTRADE, and data on trade restrictions are from UNCTAD's Trade Analysis Information System.

8 Non-tariff barriers are computed using the frequency index, which is computed as the share of traded product lines subject to at least one non-tariff barrier. 